\title{
Instrument-dependent interference of Howell-Jolly bodies in reticulocyte enumeration
}

\section{Citation for published version (APA):}

Berkel, van, M., Besselaar, E., Kuijper, P. H. M., \& Scharnhorst, V. (2013). Instrument-dependent interference of Howell-Jolly bodies in reticulocyte enumeration. Clinical Chemistry and Laboratory Medicine, 51, e137-e139. [1]. https://doi.org/10.1515/cclm-2012-0790

DOI:

10.1515/cclm-2012-0790

Document status and date:

Published: 01/01/2013

\section{Document Version:}

Publisher's PDF, also known as Version of Record (includes final page, issue and volume numbers)

\section{Please check the document version of this publication:}

- A submitted manuscript is the version of the article upon submission and before peer-review. There can be important differences between the submitted version and the official published version of record. People interested in the research are advised to contact the author for the final version of the publication, or visit the $\mathrm{DOI}$ to the publisher's website.

- The final author version and the galley proof are versions of the publication after peer review.

- The final published version features the final layout of the paper including the volume, issue and page numbers.

Link to publication

\section{General rights}

Copyright and moral rights for the publications made accessible in the public portal are retained by the authors and/or other copyright owners and it is a condition of accessing publications that users recognise and abide by the legal requirements associated with these rights.

- Users may download and print one copy of any publication from the public portal for the purpose of private study or research.

- You may not further distribute the material or use it for any profit-making activity or commercial gain

- You may freely distribute the URL identifying the publication in the public portal.

If the publication is distributed under the terms of Article 25fa of the Dutch Copyright Act, indicated by the "Taverne" license above, please follow below link for the End User Agreement:

www.tue.nl/taverne

Take down policy

If you believe that this document breaches copyright please contact us at:

openaccess@tue.nl

providing details and we will investigate your claim. 


\section{Letter to the Editor}

\section{Miranda van Berkel*, Eveline Besselaar, Philip Kuijper and Volkher Scharnhorst Instrument-dependent interference of Howell-Jolly bodies in reticulocyte enumeration}

Keywords: Howell-Jolly bodies; red blood cells; reticulocytes; state-of-the-art hematology analyzer.

\footnotetext{
*Corresponding author: Miranda van Berkel, PhD, Clinical Laboratory, Catharina Hospital, Michelangelolaan 2, 5623 EJ Eindhoven, The Netherlands, Phone: +31 402396381 , Fax: +31 40 2398614, E-mail: miranda.v.berkel@cze.nl Eveline Besselaar: MD, Internal Medicine, Catharina Hospital, Eindhoven, The Netherlands

Philip Kuijper: PhD, Clinical Laboratory, Máxima Medical Center, Veldhoven, The Netherlands

Volkher Scharnhorst: PhD, Clinical Laboratory, Catharina Hospital, Eindhoven, The Netherlands
}

To the Editor,

Reticulocyte enumeration in peripheral blood is an important diagnostic procedure in the evaluation of erythropoiesis in bone marrow. Traditionally, reticulocytes are counted after staining with basic dyes such as Brilliant Cresyl Blue (BCB) or new methylene blue (NMB), which stain the RNA containing reticulofilamentous material in vitally stained unfixed preparation of cells on a glass slide [1]. In subsequent microscopic evaluation, reticulocytes can be discriminated from mature red blood cells by an intracellular deep blue precipitate. Nowadays, state-of-the-art hematology automatic counters replace the labor intensive microscopic evaluation of reticulocytes with quick and reliable enumeration of reticulocytes in whole blood samples [2]. The technique is based on specific dyes, which mostly are polynucleotide-specific, thus binding DNA as well as RNA [2]. Here, we describe a recently observed case where two out of three state-of-theart hematology analyzers displayed a strong discrepancy with manual counting in reticulocyte enumeration due to the presence of Howell Jolly bodies.

A 38-year-old male visited the outpatient clinic of internal medicine with general symptoms of decreased well-being, suffering from fatigue, loss of concentration and paraestesia after gastric bypass surgery 8 years ago. This surgery had been complicated by stomach bleeding and was followed by splenectomy. The laboratory tests showed strong reticulocytosis $\left(440 \times 10^{9} / \mathrm{L}\right.$; ref. value $30-120 \times 10^{9} / \mathrm{L}$ ) with normal number of erythrocytes $\left(4.8 \times 10^{12} / \mathrm{L}\right.$, ref. value $\left.4.5-5.5 \times 10^{12} / \mathrm{L}\right)$ and hemoglobin (Hb) content (148 g/L, ref. value 136-177 g/L) (analyzed with a CELL-DYN Sapphire analyzer) and a vitamin B12 deficiency (136 pg/mL, ref. value 189-948 pg/mL). Differential leukocyte count showed a minimal leukocytosis $\left(11.4 \times 10^{9} / \mathrm{L}\right)$ caused by lymphocytosis. There were no laboratory findings indicating hemolysis (bilirubin and lactate dehydrogenase within reference ranges and normal concentration of haptoglobin). The reticulocytosis in combination with normal erythrocyte- and $\mathrm{Hb}$ concentrations was an indication for further microscopic examination. The blood smear showed the presence of a striking number of Howell-Jolly bodies in red blood cells ( $8 \%$ of all erythrocytes, Figure 1). This prompted us to re-evaluate the number of reticulocytes in a subsequent blood sample drawn from this patient. As a reference method, reticulocytes were evaluated microscopically after supravital BCB staining, resulting in a percentage of reticulocytes of $1.2 \%$ of total erythrocytes. Automated counting with three systems using different methods for reticulocyte enumeration showed a strong discrepancy between the methods used (Table 1). While Beckman Coulter LH 750 automated counter produced a reticulocyte percentage resembling the $\mathrm{BCB}$ staining and manual counting $\left(1.1 \%\right.$, absolute $49 \times 10^{\%} / \mathrm{L}$, reference $30-120 \times 10^{9} / \mathrm{L}$ ) both Sysmex XE-5000 and especially CELL-DYN Sapphire counted falsely elevated reticulocytes $\left(94 \times 10^{9} / \mathrm{L}\right.$ and $377 \times 10^{9} / \mathrm{L}$, respectively, reference $\left.30-120 \times 10^{9} / \mathrm{L}\right)$.

The interference of nucleic acid containing structures present in erythrocytes in the correct determination of reticulocytes has been described for automatic hematological cell counters. For example, the presence of Pappenheimer bodies, basophilic stippling and Heinz bodies were reported to result in falsely elevated reticulocyte numbers [3]. Malaria parasites in erythrocytes, although they are usually faintly stained, caused spurious elevated reticulocyte counts using CELL-DYN 4000 automatic systems [4]. Also, the presence of HowellJolly bodies interferes with the automated reticulocyte 


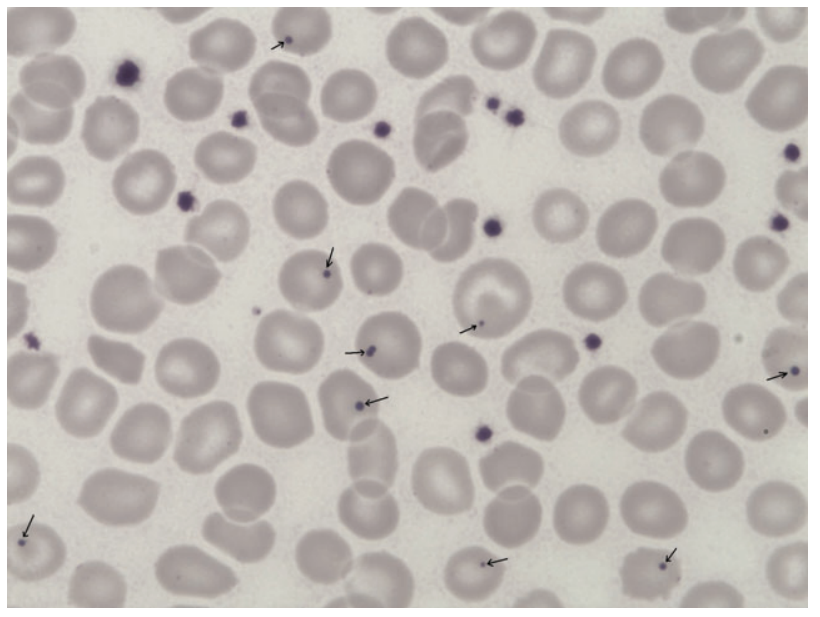

Figure 1 Howell-Jolly bodies included in erythrocytes. A blood film was stained with May-Grünwald-Giemsa (original magnification 630×). Howell-Jolly bodies are indicated with arrows.

counting using Coulter Epics Profile II flow cytometer, resulting in falsely elevated levels [5]. In our evaluation, counting with Beckman Coulter LH 750 generated reticulocyte numbers comparable to microscopic examination after supravital BCB staining, while CELL-DYN Sapphire and - to a lesser extent - Sysmex XE-5000 counted falsely elevated numbers of reticulocytes. This discrepancy might be explained by the analyzer-specific staining, detection and gating strategies used. Beckman Coulter LH 750 stains blood cells with new methylene blue, a colorimetric dye comparable to $\mathrm{BCB}$, and discriminates reticulocytes from other cells by volume, conductivity, and laser light scatter; the latter signal is proportional to the residual RNA within the red cell. This staining is specific for RNA remnants in reticulocytes [2]. In contrast, Sysmex XE-5000 and CELL-DYN Sapphire instruments use fluorescent dyes, staining polynucleotides within cells. CELL-DYN Sapphire combines a cyanine dye (Sybr Ii) and narrow angle light scattering to separate reticulocytes from platelets, RBC and nucleated cells $[2,6]$. Sysmex XE-5000 uses similar techniques, with polymethine dye, and forward light scattering differentiating platelets and $\mathrm{RBC} /$ reticulocytes based on cell volume. The variation between these two analyzers in reticulocyte concentration possibly results from a combination of different dyes with different subgating strategies.

\begin{tabular}{lrrrr} 
& $\begin{array}{r}\text { Abbott } \\
\text { CELL-DYN } \\
\text { Sapphire }\end{array}$ & $\begin{array}{r}\text { Sysmex } \\
\text { XE-5000 }\end{array}$ & $\begin{array}{r}\text { Beckman } \\
\text { Coulter } \\
\text { LH 750 }\end{array}$ & $\begin{array}{r}\text { BCB } \\
\text { staining }\end{array}$ \\
\hline Reticulocytes, $\times 10^{9} / \mathrm{L}$ & 377 & 94 & 49 & \\
Reticulocytes, \% & 7.9 & 2.0 & 1.1 & 1.2 \\
RBC, $\times 10^{12} / \mathrm{L}$ & 4.7 & 4.6 & 4.5 & \\
\hline
\end{tabular}

Table 1 Reticulocyte numbers evaluated using different techniques. Blood was collected into $K_{3}$ EDTA containing tubes (Vacutainer ref. 3688610, Becton Dickinson BV, Breda, The Netherlands) and blood counts were measured within $6 \mathrm{~h}$ on a Beckman Coulter LH 750, a Sysmex XE-5000 and a CELL-DYN Sapphire (Abbott Diagnostics) automatic hematology analyzer. A blood film was prepared and stained with either May-Grünwald-Giemsa or Brilliant Cresyl Blue (BCB) staining. For the automatic counter, reticulocytes are expressed as a percentage of total erythrocytes as measured by the particular analyzer. After supravital BCB staining 1000 reticulocytes were manually counted (1000 erythrocytes were evaluated).

Overall, the use of polynucleotide-specific fluorescent dye in state-of-the-art hematological analyzers such as Sysmex XE-5000 and CELL-DYN Sapphire can cause pseudoreticolocytosis in the presence of HowellJolly bodies or other nucleic acid remnants. This is not observed using an RNA-specific dye in Beckman Coulter LH750 instruments. Therefore, the reticulocyte numbers obtained with automatic hematological counters can be spuriously elevated and need to be interpreted with caution in the presence of nucleic acid containing inclusions. This case underlines that improvement of some automatic hematology analyzers with respect to the detection of reticulocytes is necessary and achievable, thereby contributing to a better standardization of automated reticulocyte enumeration.

\section{Conflict of interest statement}

Authors' conflict of interest disclosure: The authors stated that there are no conflicts of interest regarding the publication of this article. Research funding: None declared.

Employment or leadership: None declared. Honorarium: None declared.

Received November 20, 2012; accepted December 4, 2012; previously published online January 8, 2013

\section{References}

1. Lewis SM, Bain BJ, Bates I. Practical hematology, 10th ed. Philadelphia: Churchill Livingstone, 2006.
2. Piva E, Brugnara C, Chiandetti L, Plebani M. Automated reticulocyte counting: state of the art and clinical applications 
in the evaluation of erythropoiesis. Clin Chem Lab Med 2010;48:1369-80.

3. Zandecki M, Genevieve F, Gerard J, Godon A. Spurious counts and spurious results on hematology analyzers: a review. Part II: white blood cells, red blood cells, haemoglobin, red cell indices and reticulocytes. Int J Lab Hematol 2007;29:21-41.

4. Hoffmann JJ, Pennings JM. Pseudo-reticulocytosis as a result of malaria parasites. Clin Lab Haem 1999;21:257-60.
5. Lofsness KG, Kohnke ML, Geier NA. Evaluation of automated reticulocyte counts and their reliability in the presence of Howell-Jolly bodies. Am J Clin Pathol 1994;101:85-90.

6. Kim YR, Kanzor J, Landayan M, Kihara J, Bearden J, Sheehan E. A rapid and sensitive reticulocyte method on a high throughput hematology instrument. Lab Hematol 1997;3:19-26. 